\section{Visión Electrónica Más que un estado sólido \\ https://doi.org/10.14483/issn.2248-4728}

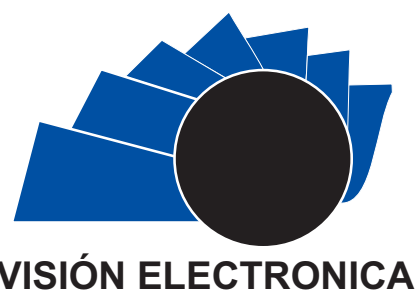

A Research Vision

\title{
ICTs as promoters of diversity and the training of child educators
}

\author{
Las TIC como promotoras de la diversidad y la formación de educadores infantiles
}

Carmen Aura Arias-Castilla ${ }^{1}$, Jaime Alberto Ayala-Cardona²,

\section{INFORMACIÓN DEL ARTICULO}

Historia del articulo

Enviado: 26/10/2018

Recibido: 05/11/2018

Aceptado: 06/12/2018

\section{Keywords:}

Childhood,

Information and Communication

Technologies ICT,

Pupil integration (Inclusion),

Teacher education.

\section{Palabras clave:}

Infancia,

Tecnologías de la información

y la comunicación TIC,

Integración de los alumnos

(inclusión),

Formación docente.

\begin{abstract}
This article emerges from the research framework "State of art at a national level of early childhood education in and for diversity", as part of the project "Pedagogical architecture, didactic and technology for teacher-training for diversity" co-financed by COLCIENCIAS and which is also part of the "Alliance of institutions for the development of education and technology in Colombia" AIDETC, seeking to identify national trends of teacher-training in early childhood education to orient training programs for teachers in and for diversity in Colombia. The inquiry has considered of great importance the incorporation of technological resources to support programs regarding diversity, thus this article presents the current trends of use, possibilities, ICT use and appropriation to accept diversity in Colombia, result of inquiry at Colombian universities with early childhood education programs, through the selection of programs, the documentary analysis of their curricula and application of interviews, to interpret the inclination of the programs in the use of technology tools for teacher-training and in this way provide a general look that enriches the processes of appropriation of ICTs within early childhood education programs.
\end{abstract}

\section{RESUMEN:}

Este artículo surge en el marco de la investigación "Estado del arte a nivel nacional de la educación infantil en y para la diversidad", como parte del proyecto "Arquitectura pedagógica, didáctica y tecnológica para la formación docente para la diversidad" cofinanciado por COLCIENCIAS y que también forma parte de la "Alianza de instituciones para el desarrollo de la educación y la tecnología en Colombia" AIDETC, buscando identificar tendencias nacionales de formación docente en educación infantil temprana para orientar programas de capacitación para docentes en y para la diversidad en Colombia. La investigación ha considerado de gran importancia la incorporación de recursos tecnológicos para apoyar programas de diversidad, por lo que este artículo presenta las tendencias actuales de uso, posibilidades, uso y apropiación de las TIC para aceptar la diversidad en Colombia, resultado de la investigación en universidades colombianas con programas de educación infantil a través de la selección de programas, el análisis documental de sus currículos y la aplicación de entrevistas, para interpretar la inclinación de los programas en el uso de herramientas tecnológicas para la formación docente, y en esta forma se proporciona una mirada general que enriquece los procesos de apropiación de las TIC en los programas de educación de la primera infancia.

\footnotetext{
${ }_{1}$ MSc. In Education, Pontificia Universidad Javeriana, Colombia. Current position: Research Professor at Group of Research and Education and Scenarios of Pedagogical Construction GIEEP, in Corporación Universitaria Iberoamericana, Colombia. Current position: Professor at the Universidad Pedagógica Nacional, Colombia. E-mail: carmen.arias@iberoamericana.edu.co.oRCID: http://orcid.org/o000-0002-4818-3913.

2Bsc. In Pedagogy of Independent Learning. Current position: Research Teacher of the Group of Research and Education and Scenarios of Pedagogical Construction GIEEP, in Corporación Universitaria Iberoamericana, Colombia. Professor in Social Sciences at Universidad Distrital Francisco José de Caldas, Colombia. E-mail: jaime.ayala@ibero.edu.co. ORCID: https://orcid.org/O000-0002-4744-6590. 


\section{Introduction}

The research on teacher training trends in Children's Pedagogy in and for diversity, initiated with the identification of a series of questions about teacher training, the incorporation of new strategies and tools to address early childhood education, the recognition and acceptance of the diversity of childhoods, which raised the need to see where trends in higher education flow on the training of educators for inclusion and diversity in Colombia.

This need pondered a recognition of the resources potentialities and technological tools in the educational contexts for the education of all and their innate need to be incorporated in the formation of new generations of teachers that look after early childhood, which required an understanding of the use of ICTs Information and Communication Technologies in Child Pedagogy Programs and similar terms, their conception, their use as pedagogical strategies linked to education and their value in attention to diversity.

\section{I C Ts in Education}

In the process of research on training trends in the Children's Pedagogy programs in and for diversity, it became relevant to start with a study to identify the emerging issues in Information Technology and Communication (hereinafter ICTs) with an initial exercise of documentary review, with which emerged themes ranging from policies of inclusion, globalization and diversity to standards and competencies in the use of ICTs.

These themes allow an exercise in the categorization of ICTs, which have been consolidated from different perspectives; a first reference is found in a text about the concepts of information technologies in which ICTs are defined as:

Technological devices (hardware and software) that allow to edit, produce, store, exchange and transmit data between different information systems with common protocols. They integrate information media, telecommunications and networks that enable communication and interpersonal collaboration and multi-directionality (one to many or many to many). They play a substantive role in the generation, exchange, dissemination, management, and access to knowledge, [1].

Going forward on the definition and development of the concept of ICTs, it is to rescue a work of compilation of definitions that have been given until 2015 and in which ICTs are identified with some definitions that describe as lax like, for whom ICTs are a: "Set of codes and devices (digital) that intervene in the stages of coding, processing, storage and communication of information in its different forms: alphanumeric, iconic and audiovisual", [2]. They also cite in the same article, definitions who restricts the concept of ICTs as: "Technologies that allow information to be transmitted anytime, anywhere", [2].

In the same study, other definitions emerge allowing to recognize the broad spectrum of influence of ICTs in modern societies, such as the conception, who sustain that they understand ICTs as a "revolutionary, impacting and changing phenomenon, which encompasses both technical and social aspects and which permeates all human, labor, educational, academic, leisure and consumer activities", [2].

This broad perspective directly connects an important human area such as education, in which ICTs are also assumed as effective tools for learning, emphasizing that:

"[...] these technologies make it possible, by eliminating spatial and temporal barriers, that more people can access training and education. On the other hand, thanks to multimedia and Internet technologies, new resources and educational possibilities are available", [3].

It is noteworthy that ICTs, not only improve the possibilities of learning, which is in some cases difficult to elucidate, due to the large number of factors associated with school contexts and which also implies the conditions and possibilities of technological resources with which in addition, it is important to highlight the recognition of ICTs in the processes of transformation of pedagogical practices by teachers, their work and the development of their daily activities in the classroom.

\subsection{ICTs and teacher training}

ICTs and its use in the training processes of new early childhood teachers, appear in the background review that has been generated on the subject and that should be mentioned in this article: "Ways to incorporate ICTs in two careers pedagogy in a regional university", [4]. In this document, the Ministry of Education of Chile defines elements that are considered constitutive of standards of teacher professional training in ICTs and raises important elements such as profiles and resources to assume technologies as tools that promote and enable learning of students in school contexts. ${ }_{i}^{n}$

Likewise, [4], in their review, show that the difficulties 
to generate processes hat incorporate ICTs in Education, as in Education Faculties are real, since it is not evident the incorporation in teachers training, or in their work as Education professionals, but in some cases is limited to access to learning platforms interceded by ICTs.

For this reason, it has been a priority to define policies in Education that incorporate ICTs, and that allow the recognition of seen technologies, according to Castell, and cited by [5], "as a fundamental source of productivity and power for the new technological conditions that arise in this historical period".

For this reason, a document entitled "UNESCO ICT Competency Framework for Teachers" was created by UNESCO [6], which aims to guide member countries in the type of approach required to the incorporation and articulation of ICTs, and counts with a progressive development program.

This framework serves as a starting point, for the Colombian case, of the document "ICT Competencies for teacher professional development", that defines a route and defines five competency levels in the use of ICTs: "Technological Competence, Pedagogical Competence, Communicative Competence, Management Competence and Investigative Competence", [7].

Given that the purpose of the framework, it is to advance the training of teachers, so that the use of ICTs is not restricted to the technological infrastructure, nor to the digital literacy of teachers, but to training in technologies for use as a teaching tool, task in which it is required the commitment of the Education Faculties.

\subsection{Potentialities of ICTs in attention to diversity}

From the reflection and analysis of these documents, and having in mind that the research was interested in characterizing the processes and implementation of ICTs in Children's Pedagogy programs, from an approach that includes attention to diversity, it is important to note that for some years the potential that ICTs has for fostering diversity has been considered, and despite the conceptual confusions of the time, [8], points to two specific uses of technology: one pedagogical "to reach an optimal level" and another Equalizer of opportunities "to facilitate participation", defining a role for ICTs in the Educational context that serves as a guideline to the processes of incorporating technologies for inclusion.

Similarly, [9] review the studies that support the potential of ICTs in the Educational attention to the diversity of students, arriving to conclude that:
... it is necessary to promote the use of ICTs so that students can experiment and learn, and above all, be part of the collective knowledge. In addition, it is important to consider how ICTs offer opportunities to improve performance in activities and how to increase participation, [9].

It is evident that there are not many similar references explicitly to the use of ICTs for attention to diversity, in both national and international documents, although some competences that have to be developed in teachers training for the use of ICTs are recognized. ICTs that imply the recognition of differences in students, it is based on [6], [7] proposed a document on ICTs Competences for teachers professional development, in the which presents several types of competences: Technological competence, communicative competence, pedagogical competence, management competence and investigative competence, the mention in which the "Design of learning environments mediated by ICTs according to cognitive, physical development, psychological and social development of my students to encourage the development of their to address some competences related to diversity", [7].

therefore, it has an impact on the daily development of classroom activities, which is why research and this article highlights what Colombian universities that train early childhood teachers are developing to promote inclusive education, by developing the possibilities of technologies as obvious actions of attention to diversity, since "The access to education for diverse population opens when the educational service is oriented for a lifetime, when teaching is diversified and contents are constantly adapted, according to the needs $[\ldots],[10]$.

Complementarily, when taking the document of the "National policy to promote the inclusion and development of the population in a situation of disability through access, use, appropriation and use of ICTs", [11], it is identified as relevant and taken the real needs of people with disabilities as important aspects, and therefore, it is pertinent to emphasize their situation.

\subsection{Diagnosis of the situation of people with disabilities in Colombia}

Data provided by the World Health Organization and the World Bank in the summary document "World Report on Disability" , [12], establishes that there is an increase in the number of people with disabilities related to the continuous aging of the world population and the age-specific diseases in people, which are marked by aspects such as "trends in health problems 
and environmental and other factors, such as traffic accidents, natural catastrophes, conflicts, eating habits and substance abuse", [12].

In the educational aspect, the same report found that "children with disabilities are less likely than their nondisabled counterparts to enter school, stay in school and pass successive courses", and the rates of Children who attend school ranges from $10 \%$ to $60 \%$ depending on the countries. Similarly, the access to ICTs for people with disabilities is so limited that it only reaches $2.2 \%$ of the population, [11].

These low rates of access and use of information and communications by populations in situations of disability have generated what the Ministry of Information Technology and Communications in the aforementioned "National policy to promote inclusion and development of the population with disabilities through access, use, appropriation and use of ICTs" recognizes as a very strong process of inequality that, in the words of the Ministry, "translates into low educational levels, low possibilities of social participation, politics, economic and also, low possibilities for personal development", [11].

These statistics make it indispensable to identify how the training of new generations of teachers in Colombia is taking advantage of the use of ICTs, to generate opportunities, through inclusive processes, of a quality education accessible to all, understanding that: "ICTs favor the implementation and development of new and better practices that are effective and in line with the real needs of the educational process", [10].

\section{Method}

Overall, the research was conceived as a qualitative documentary with a hermeneutic approach, [13] that allowed an interpretative process that gives meaning to the texts about the reality of child pedagogues training in and for diversity in Colombia.

In order to identify the trends of use of Information and Communication Technologies for the inclusion of diversity in Child Pedagogy Programs, were established two moments, initially one that aimed at the content analysis of the study plans where reviewed 34 Child Pedagogy Programs and similar terms, selecting 11 that evidenced having courses with denominations referring to educational attention in and for diversity, with whom it was made a more detailed analysis of the existing information within the Program and other documents. They contextualized the information of the eminently hermeneutical programs, and then a second moment that initiated gathering information from teachers and students of the Program to confirm the information analyzed in a documentary manner focused on collecting the information from the same universities and in the same spaces of the Programs. This type of methodological exercises, where the documentary review is complemented with the application of other instruments, to collect information on the state of the art as well, is common in cases such as [14] where in the methodology of the State of the art on the elaboration of policies for the professional training of teachers, it is mentioned that not only an interview but a survey was carried out to complement the sources of information: "...survey specially constructed for this study and that was answered by educational authorities of Costa Rica, Cuba, El Salvador, Guatemala, Honduras, Nicaragua, Panama, the Dominican Republic and Venezuela.", [14].

For the investigation case, the interviews were submitted to expert judges and then again adjusted to be applied in each of the eleven Colombian universities, selected for having some course with a denomination that refers to processes of inclusion and educational attention to diversity, and also referred to ICTs in the training of future childhood educators, as will be explained later.

The obtained information was digitized and systematized to be analyzed hermeneutically in categories (theoretical or established a priori) and subcategories (emerging), which were related through semantic networks generated through the Atlas.ti software (v. 7.5.2) that allowed to identify how the categorical structure of the project is conceived.

The analysis is focused on categories, each of them is divided into subcategories that arose in an emergent manner that is, taking into account the information of the participants. In most cases, all the issues were addressed with both actors involved and this undoubtedly allowed enriching the findings from both perspectives, for this article the obtained results are presented in the category of "Technological and didactic human resources".

\section{Results: Trends in Colombian Universities}

In the identification of Child Pedagogy programs or similar terms, the 34 Programs present in Colombia in the National Higher Education Information System, SNIES, were taken as a starting point, and a matrix of course selection was designed and validatied to make it possible to note their tendency in and ${ }^{i}$ for diversity, based on the definition of two criteria in its curriculum; one, that had courses that in their denomination were 
referring to diversity, educational needs and inclusion, and other courses with denominations referring to ICTs, didactic aspects of ICTs in educational contexts, ICTs for learning, ICTs didactics and technologies for inclusion.

This selection yielded 11 Programs that evidenced some sort of tendency to diversity and it was made an analysis of the content of the courses of their study plan.

In this content analysis of the research it is noteworthy that in the category of courses with denominations referring to ICTs courses were found that by their descriptions, competences, and contents, were evidenced are focused on childhood learning in the Programs and therefore they see ICTs as a pedagogical option, with courses such as: Educational Innovation, Computer Science I and Computer Science II, Virtual Environments II, ICTs in Education, Educational Computing, Mediations in Education and ICTs, ICTs III, ICTs applied to education, ICTs and learning environments, ICTs in childhood and finally ICTs in Education, [10].

This analysis allowed recognizing the presence of a pedagogical intentionality in the use of ICTs in the processes of teacher training and the recognition of technologies as enablers of inclusive educational processes, so that the Child Pedagogy Programs and similar terms are providing the tools for future early childhood teachers to take ownership of ICTs and put them at the service of education and inclusion.

This is how these progress in teacher training processes for attention to diversity from ICTs, allows advance in the understanding of the type of contemporary classrooms in which, as [15] put it, "... there are points different starting points, different interests, motivations and learning rhythms ", that require tools and innovations that technologies have the potential to provide.

On the other hand, we continued with the visit to the Universities for the application of the instruments that allowed us to confirm what was stated in the courses in an institutional way, which is done through the voices of the professors, students and administrative staff of the Programs of Child Pedagogy or similar terms, and note the trend in the use of ICTs as promoters of fostering diversity from the early childhood teacher training programs.

As relevant elements within the application of instruments emerge the category of "Human, technological and didactic resources" in which the following aspects were identified that allowed to identify the use of ICTs in each of the selected universities:

At the Pontificia Universidad Javeriana, the existence of the "Include Group" (Grupo Incluir) was found as a management center to strengthen inclusion at the institutional level. There are developed committees and proposals for policy formulation, infrastructure adjustments, teacher training, and development of innovative ideas, research, and reference to support centers (as a psychological care center or writing center). In the case of Universidad de Santiago de Cali, monitoring, systematization and reporting processes are carried out for the support of the Psychology Department or the Reading and Orality Center.

In the case of the Corporación Universitaria Iberoamericana, Braille was identified within the facilities, braille books were available, JAWS software installation, Braille line in the library's computers, and the projection was identified at the Pontificia Universidad Javeriana. of the opening of a specialized room for blind people that will have that same type of technology for access to information, in the same way the University has the Closed Caption System in the television sets of the institution and it was found that they are carrying out the management so that you have the interpretation of LSC in videos, even though you already have the interpretation service in LSC during academic forums.

The Pontificia Universidad Javeriana also found the existence of the Center for the Promotion of Identity and the Construction of the Community in the University, which not only works for the inclusion of people with disabilities, which is the focus of the Inclusive Group, but also of people living on the border and other vulnerable populations susceptible to suffer exclusion.

Likewise, the "Universidad del Norte" found the existence of an Extension Office that is in charge of systematizing and supporting inclusion processes, especially in terms of disability and the presence of a Resource Center for Student Success was noted (CREE), which is a program to take action in case of learning problems (other than disability); and on the other hand the creation of the Center for Teaching Excellence (CED), conceived as a space to support the work of teachers in aspects related to training in Pedagogy.

In contrast to the information systems available to Universities to identify and characterize their students, 
as a technological aspect at the service of the processes of fostering diversity, it was noted that the institutions have systems such as the Pontificia Universidad Javeriana, whose registration system includes a section for the identification of students with disabilities and which allows for the management of support resources for students who require it.

In the same way, the Universidad Santiago de Cali evidenced systems that allow the characterization of cases in the admission and access process and through the enrollment system for resource management according to the student's condition, which is similar to the findings in the Corporación Universitaria Rafael Núñez, that also found an identification system on admission and that was found to have teacher training processes based on that initial identification, these programs appear as common in most universities, since in the Corporación Universitaria Iberoamericana was also found a program for the characterization and monitoring of students.

Regarding the use of various technological tools by teachers, it was evidenced in the Corporación Universitaria Rafael Núñez that they have the resources so that through the use of technologies, adjustments are been made to make information about documents, presentations, etc. accessible for the classes, very relevant aspect to specify the inclusion processes in the Program.

Among the tools, it was identified that the Programs have Platforms for virtual learning (Moodle), some of them like the Universidad Santo Tomas, that are equipped with courses that allow a simple exploration for the different students with inclusion processes, also the Corporación Universitaria Iberoamericana, the Universidad del Tolima, the Universidad del Amazonas, among others, have accessible virtual platforms.

Other aspects in which technology is used, are in monitoring and/or tutoring as a learning support and promotion resource for all students, which is a common factor in all the universities surveyed and an aspect that promotes processes of inclusion in higher education, since they allow for the necessary support and follow-up on student learning.

\section{Discussion and Conclusions}

According to what was established in the application of the interviews, it was found that the universities have numerous ICTs resources and materials and their use is very varied, ranging from the systematization and characterization of students to support their training process, to the technologies for the necessary support and reasonable adjustments in cases of student diversity, this in terms of identifying trends in technological resources.

In relation to the presence of specialized support professionals, when analyzing the results, it is striking to note that it is especially spoken of interpreters of Colombian Sign Language (LSC). It is emphasized that within several institutions, there are professionals that make possible the inclusion of the Deaf population, although only in the Corporación Universitaria Iberoamericana it was indicated that there is an Interpreters Coordination and that their salary is assumed by the university and not by the included students. This is fundamental considering that part of the rights of this population has to do with receiving the specialized support they need to access information and communication with equity and relevance, [16].

Similarly, there is strong evidence of the existence of technological resources in the universities for the inclusion of blind population. Advances stand out and there are institutions that are developing and promoting the acquisition of this type of material through resources provided by the Ministry of Information Technology and Communications, [17], through the "ConVertic" page with the Jaws and Magic software, even though other technological tools or physical resources are not mentioned, but it emerges as of high relevance in the perspective of the institutions.

On the other hand, it should be noted that it was not possible to determine the existence of profiles of other types of support professionals, other than interpreters, such as classroom teachers for the deaf population, linguistic models, typists, interpreter-guides, therapists (of different types), among others. What is considered as an opportunity is the work that is been developed or is going to be initiated within the universities, and it will broaden the spectrum in the training provided to the next children's educators.

However, it would be worth highlighting that in some cases it is very likely that there will be other types of ICT tools and resources to support the training processes for inclusion by the Universities, but that are not known by teachers and students, before which it is essential that its recognition and use be promoted, but it is to be noted that the obtained and proposed results in this article and throughout the investigation respond to the information provided by the institutions and the focus groups of teachers and students.

In conclusion, these aspects and the obtained results reinforce the imperative need to train teachers of future 
generations with all the pedagogical and technological tools to embrace diversity, as proposed by Paya Rico as an inescapable act "remembering the need for initial and permanent teacher training to address diversity" [18] linking in that training those material and technological resources that allow increasing the learning and participation possibilities of all people.

In this order of ideas, it is fundamental to generate mechanisms that allow the creation of flexible environments, focused on the student, thinking about the acquisition of software and hardware created universally, with the intention of promoting increased learning and the participation of all students in the classroom, [19]. Similarly, access to physical material that conforms to the determinations of Universal Design should be considered and it should illustrate the main ideas through multiple means, providing alternatives to the text and making explicit the relationship between the text and said alternatives, [20].

It is evident that Colombian universities have made great and positive steps in the use of ICTs in the training processes of teachers to welcome diversity, and although there is still a long way to go, it is worthwhile to advance in the use of the potential that technologies have as promoters of fostering diversity.

\section{Acknowledgments}

The research "State of art at a national level of Children's Pedagogy in and for diversity", carried out within the "Pedagogical, didactic and technological architecture project for teacher training in and for diversity" code 14196614547656, was co-financed by the Administrative Department of Science, Technology and Innovation - COLCIENCIAS in Colombia, by contract 0546-2014 corresponding to the announcement N. 661-2014 -Education, Peace and Equity- and also with the Corporación Universitaria Iberoamericana resources, [21].

\section{References}

[1] J. C. Cobo-Romaní, "El concepto de tecnologías de la información. Benchmarking sobre las definiciones de las TIC en la sociedad del conocimiento", Revista de Estudios de Comunicación-ZER, vol. 14, no. 27, 2009, pp. 295-318.

[2] M. Grande, R. Cañón and I. Cantón, "Tecnologías de la información y la comunicación: Evolución del concepto y características", International Journal of
Educational Research and Innovation, no. 6, 2016, pp. 218-230.

[3] C. Coll, "Aprender y enseñar con las TIC: expectativas, realidad y potencialidades", 2008. [ $\mathrm{O} n \mathrm{line}]$. A v a i l a b l e a t: https://www.educ.ar/recursos/70819/aprend er-y-ensenar-con-las-tic-expectativasrealidad-y-potencialidades.

[4] J. Garcés-Bustamante, C. Núñez and J. Aroldo, "Formas de incorporación de las tecnologías de la información y comunicación (TIC) en dos carreras de pedagogía de una universidad regional", Horizontes Educacionales, vol. 15, no. 2, 2010, pp. 11-21.

[5] H. Muñoz-Rojas and J. Núñez-Valero, "Caracterización de las políticas públicas educativas relacionadas con tecnologías de la información de la comunicación, TIC, en Colombia", thesis MSc., Universidad de La Salle, Colombia, 2008.

[6] UNESCO, "UNESCO ICT Competency Framework for Teachers", 2011. [Online]. A va i l a ble a t : http://unesdoc.unesco.org/images/0021/002 134/213475e.pdf.

[7] Ministerio de educación de Colombia, "Competencias de desarrollo profesional docente", 2013. [Online]. Available at: http://www.colombiaaprende.edu.co/html/mi crositios/ $1752 /$ articles 318264 recurso tic.pdf.

[8] R. Sánchez-Montoya, "Ordenador y discapacidad", 2002. [Online]. Available at: http://capacidad.es/capitulo1.pdf.

[9] J. Ribeiro and S. Sánchez, "Inclusión educativa a través de las TIC”, Indagatio Didactic, vol. 5, no. 4, 2013, pp. 147-160.

[10] C. Arias-Castilla, J. A. Ayala-Cardona and M. Suárez-Bejarano, "Antecedentes en la formación de docentes de pedagogía infantil en y para la diversidad”, Hexágono pedagógico, vol. 7, no. 1, 2016. 
[11] Ministerio de Tecnologías de la Información y las Comunicaciones, "Política nacional para promover la inclusión y el desarrollo de la población con discapacidad a través del acceso, uso, apropiación y aprovechamiento de las TIC", 2012. [Online]. Available at: http://www.telecentros.org.co/apc-aafiles/64736664736673646673646673646673/ 5nov.pdf.

[12] World Health Organization, "World Report on disability", 2011. [Online]. Available at: https://www.who.int/disabilities/world_repo rt/2011/report.pdf.

[13] O. Londoño-Palacio, L. Maldonado-Granados and L. Calderón-Villafáñez, "Guía para construir estados del arte", 2014. [Online]. A v a i l a b l e a t : http://www.academia.edu/19163956/2014 Londo\%C3\%B10_Maldonado_y Calder\%C3\% $\begin{array}{lll}\mathrm{B} & 3 & \mathrm{n}\end{array}$ Gu\%C3\%ADa_para construir el estado de 1 arte.

[14] UNESCO, "State of the art and guiding criteria for the elaboration of policies of training and professional development of Early Childhood teachers in Latin America and the Caribbean", 2016 . [Online]. Available at: http://www.unesco.org/new/fileadmin/MUL TIMEDIA/FIELD/Santiago/pdf/PolicyGuidelines-Training-Professionaldevelopment-Earl.pdf.

[15] M. García and R. López, "Explorando, desde una perspectiva inclusiva, el uso de las TIC para atender a la diversidad", Revista de curriculum y formación del profesorado, vol. 16, no. 1, 2012.

[16] R. López-Gaviria, A. Moriña, N. MeleroAguilar and V. Perera-Rodríguez, "Proposals for the Improvement of University Classrooms: The Perspective of Students with Disabilities", Procedia - Social and Behavioral Sciences, vol. 228, 2016, pp. 175-182. https://doi.org/10.1016/j.sbspro.2016.07.026
[17] Ministerio de Tecnologías de la Información y las Comunicaciones, "Las TIC, cada vez más cerca de los colombianos en condición de discapacidad”, 2016. [Online]. Available at: http://www.convertic.gov.co/641/w3-article22323.html.

[18] A. Payá-Rico, "Políticas de educación inclusiva en América Latina”, Revista de educación inclusiva, vol. 3, no. 2, 2010.

[19] M. Izzo, "Universal Design for Learning: Enhancing Achievement of Students with Disabilities", Procedia Computer Science, vol. 14, $2012, \quad$ p p. $343-350$. https://doi.org/10.1016/j.procs.2012.10.039.

[20] C. Alba Pastor, A. Zubillaga del Rio and J. Sánchez Serrano, "Tecnologías y Diseño Universal para el Aprendizaje (DUA): experiencias en el contexto universitario e implicaciones en la formación del profesorado", Journal of Educational Technology-RELATEC, vol. 14, no. 1, 2015 , pp. 89-100. https://doi.org/10.17398/1695288X.14.1.89.

[21] C. A. Arias Castilla and J. A. Ayala Cardona, "Diversidad en educación infantil", 2018. [ O n l i n e ]. A v a i l a ble a t: http://repositorio.iberoamericana.edu.co/bits tream/001/595/1/Diversidad\%20en\%20Edu caci\%C3\%B3n\%20Infantil\%3A\%20Programas \%20de\%20Formadores\%20para\%20la\%20Infa ncia\%20en\%20Colombia. 